\title{
Ett hem till mer än namnet - om hem som källa till oberoende och identitet bland äldre med hemtjänst
}

\section{LARS EVERTSSON \& STINA JOHANSSON}

En grundbult $i$ svensk äldrepolitik är möjligheten att förbli $i$ eget boende. Hemmet betraktas som en viktig resurs för oberoende och samhällsengagemang. Intervjuerna visar dock att hemmet har en djupare innebörd. Hemmet utgör en arena och källa till oberoende och identitet. I artikeln görs gällande, att denna till synes blygsamma perspektivförskjutning-frän att se hemmet som resurs till oberoende till att se det som källa för oberoende - har betydande välfärdspolitiska implikationer för hemtjänstens framtida orientering.

Kommunal hemtjänst utgör en hörnsten i svensk äldrepolitik. I Nationell handlingsplan för äldrepolitiken betonas eget boende som en central resurs för äldres inflytande och oberoende i samhällslivet och vardagen (Regeringens prop. 1997/98:113). Betoningen på hemtjänst som äldreomsorgens

Lars Evertsson, fil. dr, institutionen för socialt arbete, Umeå universitet

Stina Johansson, professor, institutionen för socialt arbete, Umeå universitet huvudalternativ är så stark att det är rimligt att beskriva svensk äldrepolitik i termer av hemmaboendeideologi (Edebalk 1990). Men det är inte bara bland politiker som hemtjänsten är populär. Studier visar att äldre personer i behov av långvariga vårdoch/eller omsorgsinsatser föredrar hjälp från hemtjänst eller hemsjukvård framför hjälp från anhöriga (Sundström \& Johansson 2004).

Intervjuerna visar att hemtjänstens popularitet är nära kopplad till möjligheten 
att förbli i eget boende. Hem är laddat med en rad innebörder som gör det till en viktig aspekt av äldres identitet och känsla av oberoende. Mot denna bakgrund är det föga förvånande att samma intervjuer visar att den huvudsakliga kritiken mot hemtjänsten handlar om att den inte gör tillräckligt för att bibehålla omsorgstagarnas känsla av hem. Det fanns en upplevelse av att hemtjänsten bortsåg från behov och insatser kopplade till hemmet.

\section{Syfte}

Syftet med artikeln är tvåfaldigt; det första är att undersöka vilka innebörder äldre med hemtjänst tillskriver det egna hemmet samt vilken betydelse hemmet har för upplevelsen av identitet och oberoende, det andra är, att med utgångspunkt i de innebörder och betydelser som äldre tillskriver hem, diskutera vilka möjliga välfärdspolitiska implikationer detta kan tänkas medföra för hemtjänsten.

\section{Metod}

Artikeln är skriven inom det av Vetenskapsrådet finansierade projektet När vardagen blir vetenskap vars syfte är att studera hur äldre med hemtjänst upplever sin vardag. Datamaterialet utgörs av 20 semistrukturerade intervjuer vilka genomfördes i en mellanstor kommun. Urvalet gjordes i samarbete med den aktuella kommunens äldrekonsulenter (biståndshandläggare) då bedömningen gjordes att äldre med hemtjänst skulle vara svåra att nå via exempel- vis anslag i offentliga lokaler eller annonser i dagspress. Rent praktiskt gick urvalet till så att äldrekonsulenterna tillfrågade kommunens omsorgstagare ifall de önskade medverka i studien. Bakom urvalsförfarandet låg en önskan från kommunens äldrekonsulenter att skydda omsorgstagarnas personliga integritet, särskilt de med någon form av demenssjukdom. Även vi ville skydda våra intervjupersoners integritet och det valda urvalsförfarandet innebär att ingen bland hemtjänstens personal vet vilka omsorgstagare som slutligen ställde upp för intervju.

I kvalitativa studier av explorativ karaktär används ofta någon form av kriterierelaterad urvalsstrategi. Tanken är att med hjälp av på förhand bestämda kriterier definiera den tilltänka urvalsgruppen (Merriam 1994, Patton 1980). Syftet med kriterierelaterade urval är att fånga den variation som kan tänkas ha betydelse för den frågeställning man som forskare rest. I vårt fall visade sig emellertid variationen inom gruppen äldre med hemtjänst vara tämligen liten. Förklaringen till detta var enkel: hemtjänstens inklusionskriterier utövade en starkt homogeniserande effekt på urvalsgruppen. Exempelvis beviljas äldre som lever samman med någon annan person sällan hemtjänst. Att detta mönster inte är specifikt för den kommun vi studerar framgår i en rapport från Socialstyrelsen (2006) där man konstaterar att hemtjänst framförallt går till äldre som saknar partner eller barn. För vår del innebar detta att samtliga som ställde sig positiva till att låta sig intervjuas, med ett undantag, levde ensamma. Vidare befann sig samtliga intervjupersoner i vad som har kommit att kallats för 
den fjärde åldern, också det en effekt av hemtjänstens behovsbedömningskriterier. Enligt Laslett [1989](1996) kännetecknas den fjärde åldern av en tilltagande fysisk skröplighet och ett ökat beroende av andra för att klara av den dagliga livsföringen. En viss variation bland intervjupersonerna fanns dock. Av de intervjuade var fem män och 15 kvinnor. De flesta hade barn, men långt ifrån alla hade barn på orten. Samtliga hade ett mer eller mindre långt yrkesliv bakom sig och bland de intervjuade fanns såväl högre och lägre tjänstemän som arbetare, bönder och småföretagare.

Intervjuerna genomfördes i omsorgstagarnas hem. I intervjuerna ställdes frågor kring omsorgstagarnas vardag och om deras erfarenhet av hemtjänsten och dess personal. I snitt varade intervjuerna mellan en till två timmar. Samtliga intervjuer spelades in och transkriberades verbatim. De transkriberade intervjuerna analyserades $i$ flera steg. I ett första steg läste vi igenom utskrifterna och lyssnade på det inspelade materialet ett flertal gånger. Därefter följde en öppen kodning av intervjumaterialet vilket resulterade i att ett antal teman växte fram. Rent konkret innebar den öppna kodningens teman ett begreppsliggörande av det empiriska materialet. Med utgångspunkt i de teman som den öppna kodningen genererade analyserades materialet på nytt, men denna gång utifrån en selektiv kodning. Enligt Starrin et al. (1991) kan selektiv kodning beskrivas som kodning mot ett överordnande tema. Ur den selektiva kodningen framträdde "hem" som viktig aspekt av äldres upplevelse av oberoende och identitet. Under hela kodnings- och analysprocessen fanns ett nära växelspel mellan empiriska iakttagelser och teoretisk förståelse. Detta sätt att pendla mellan empiri och teori har beskrivits som ett "skapande av nyckelhål och nyckel på en och samma gång" (Berner 1989).

\section{Tre centrala begrepp: identitet, oberoende och hem}

\section{Identitet}

Begreppet identitet har som Hall (1996 s. 1) uttryckt det varit föremål för "a searching critique». Avsikten här, är dock inte att delta i den mångfacetterade debatten kring begreppet identitet. Vårt förhållningssätt till identitet är snarare pragmatiskt och selektivt i så motto att vi vill förstå hur våra intervjupersoner kopplar upplevelsen av hem till upplevelsen av identitet. Utgångspunkten är att identitet är formad och förankrad i en social och kulturell kontext. Utifrån denna, inom sociologin så vanligt förekommande interaktionistiska utgångspunkt, kan identitet inte reduceras till eller definieras utifrån individuella egenskaper och/eller förmågor (Taylor 1989). Utifrån ett interaktionistiskt perspektiv framträder identitet som något föränderligt och dynamiskt. Giddens (1991) uttrycker det som att vår identitet är ett ständigt pågående projekt. Identitetens föränderliga karaktär innebär att formeringen och upprätthållandet av identitet kräver ett reflexivt arbete. Butler (1999) menar att identitet snarare ska förstås som något vi gör snarare än är.

I det reflexiva identitetsarbetet har livsstilar en framträdande plats. Livsstilar erbjuder stadga och kontinuitet åt identite- 
ten och förser den med en social och materiell inramning.

A lifestyle can be definied as a more or less integrated set of practices which an individual embraces, not only because such practices fulfil utilitarian needs, but because they give material form to a particular narrative of self-identity(Giddens 1991 s. 81).

Hem har en framträdande plats i många livsstilar. Gorman-Murray (2006 s. 229) pekar på att hem utgör en ıimportant marker of personal identity“ och Young (1997 s. 159) hävdar att hem fungerar som "the material anchor for a sense of agency" genom att föremål i hemmet:

... supports the body habits and routines of those who dwell there. The arrangement of furniture in space provides pathways for habits - the reading lamp placed just here, the television just here, the particular spices on the rack placed just so in relation to this person's taste and cooking habits (Young 1997 s. 150).

Hemmets vanor och rutiner gör det möjligt för oss att ägna oss åt aktiviteter utan att för den skull behöva ge dem vår fulla uppmärksamhet (Varley 2008).

Men det är inte bara livsstilar som ger draghjälp åt identiteten. Även kroppen utgör en väsentlig del av identiteten. Kroppen ska primärt inte ses som en fysisk entitet utan som ett handlingssystem där kroppens praktiska deltagande i vardagslivets interaktioner utgör en väsentlig del av känslan av att ha en sammanhängande identitet (Butler 1999, Giddens 1991, Goffman 1971). Giddens
(1991) lyfter fram flera aspekter av kroppen med betydelse för hur vi och vår omgivning uppfattar vår identitet. ${ }^{1}$ Av särskilt intresse i detta sammanhang är den aspekt av kroppen som Giddens (1991) benämner uppträdande vilken handlar om hur kroppen mobiliseras i förhållande till vardagslivets konstitutiva normer. Som vi ska visa i nästa avsnitt så kan brister i förmågan att framställa sig och uppträda som oberoende utgöra ett brott mot vardagslivets konstituerande normer vilka föreskriver oberoende för vuxna individer. Den som faller utanför normaliteten i detta avseende kan få svårt att upprätthålla en sammanhängande och positiv identitetskänsla och riskerar att uppfattas som svag och oförmögen. Uttryckt i Goffmans (1972) termer skulle man kunna säga att beroende riskerar att bli till en "fläck på den personliga fasaden" eftersom vår kulturella förståelse av beroende/oberoende inrymmer en föreställning om vad det innebär att vara "fullt ut mänsklig». Sidenvall et al. (2001 s. 152) menar att:

The social discourse of Western culture denies full personhood to those who are perceived to be dependent. A person thereby risks losing their self-determination which could explain why many old people fear dependence.

\section{Oberoende}

I västvärlden har frågan om individens

1 Giddens (1991 s. 99) nämner fyra aspekter av kroppen som centrala för vår känsla av identitet. Dessa är kroppens framträdande, uppträdande, sensualitet och regimer. 
beroende/oberoende vuxit fram i anslutning till det som kommit att kallas för den possessiva individualismen (Fraser \& Gordon 1994, Hockey \& James 1993, MacFarlane 1978, Macpherson [1962] 1967). Något förenklat kan man säga att den possessiva individualismen banat väg för en föreställning att oberoende är endast den individ som 1) försörjer sig genom lönearbete, 2) rår över den egna kroppen och dess resurser, 3) står fri från andras viljor och krav samt 4) står fri från relationer som inte är självvalda eller som inte gynnar det egna intresset (Macpherson 1967 s. 263f). Hockey och James (1993 s. 52f) menar att den grundläggande metaforen för den possessiva individualismens oberoende individ utgörs av "the self-made man", en man som står socialt och ekonomiskt oberoende och som inte står i tacksamhetsskuld till någon i samhället för sitt oberoende. Denna bild förlägger vår föreställning av oberoende till den offentliga sfären. Det är först genom deltagande i den offentliga sfären som vi är oberoende. För de individer som förknippas med den privata sfären såsom kvinnor, barn, funktionshindrade och gamla finns inget oberoende att få. De är mer eller mindre dömda att socialt och kulturellt betraktas som beroende (se särskilt Fraser \& Gordon 1994). Om den grundläggande metaforen för den oberoende individen utgörs av "the self-made man" så menar Hockey och James (1993) att den grundläggande metaforen för den beroende individen utgörs av barnet. Barnet och barndom framställs som motsatsen till vad det innebär att vara vuxen och leva ett vuxenliv. Av denna anledning riskerar alla som av någon anledning framstår som beroende att infan- tiliseras. ${ }^{2}$ För äldre riskerar en förlust av oberoende att leda till infantilisering där de betraktas som oförmögna att ta hand om sig själv och fatta beslut om vad som är bäst för dem, dvs. de riskerar att inte längre uppfattas som fullt vuxna individer.

\section{Hem}

Innebörden av begreppet hem och vad hem representerar är omtvistat (för litteraturöversikter se Deprés 1991, Mallet 2004, Somerville 1997). Svårigheten att ge en entydig definition utesluter emellertid inte möjligheten att, som Borell och Johansson (2005 s. 187) säger, urskilja ett slags "hemmets minsta gemensamma nämnare». Dessa, hemmets minsta gemensamma nämnare, benämner Borell och Johansson som avskildhet, autonomi och gränssättning. Med avskildhet åsyftas hemmets privata karaktär och det faktum att hemmet är omgärdat av sociala, kulturella och fysiska gränser vilka utomstående äger rätt att passera först efter inbjudan. Vem som äger tillträde till hemmet är $\mathrm{i}$ allmänhet noga reglerat och kontrollerat och baserar sig ofta på släktskap, intimitets- eller vänskapsband. Nära relaterad till föreställningen om hemmet som en privat sfär är bilden av hemmet som en plats för självbestämmande, dvs. autonomi. Hemmet utgör en plats där vi som individer reser anspråk på att själva bestämma livsrytmen och de

2 Barron (1996) använder begreppet »den eviga barndomen" för att beskriva den infantilisering som många med funktionshinder möter i sin vardag. 
aktiviteter som där utspelar sig. Hemmet är den plats där vi som individer tillåts, eller till och med uppmanas, påverka och sätta vår personliga prägel på. Detta är inte minst tydligt i de många livsstilsorienterade media som riktar in sig på hemmet som centrum för individens estetisering av vardagslivet (se exempelvis Attwood 2005, Gorman-Murray 2006). Hemmets gränser är dock sällan statiska. Vem vårt hem står öppet för och i vilken utsträckning vårt hem är plats för självbestämmande är föränderligt. Hemmets gränser är varken permanenta eller ogenomträngliga eftersom det kring hemmet och dess användning råder en ofrånkomlig spänning mellan olika intressen (Sibley 1995). Som arena för intressen och gränssättningsaktiviteter är hem snarare att betrakta som verb än substantiv, då fokus ligger på »the diverse ways people 'do' and feel home» (Mallet 2004 s. 79).

Som Sibley (1995) och Wardaugh (1999) pekat på är förmågan att upprätthålla hemmets gränser betydelsefull för upplevelsen av att ha ett hem. För dem som av olika anledningar berövats eller inte längre förmår upprätthålla hemmets gränser kan en alienerad känsla av att vara »homeless at home« infinna sig (Wardaugh 1999 s. 96f). Hemmet som arena för intressen och gränsdragningsaktiviteter innebär emellertid inte per automatik konflikter och oenighet. Ibland sker förskjutningar av hemmets gränser utan större uppståndelse. Ett exempel på detta är den ömsesidiga förväntan som finns mellan föräldrar och barn på att vuxna barn ska flytta hemifrån (Mason 1989). I andra sammanhang kan förskjutningar av hemmets gränser ge upphov till spänningar. Ett sådant exempel är när vård- och omsorgsinsatser tar steget över tröskeln in i den enskilde omsorgstagarens hem. För personalen kan hemmets privata karaktär leda till en känsla av osäkerhet och ambivalens inför arbetet då:

... they are in some measure bound by the norms of being a guest. These mean that you have to ask permission both to enter and to do certain things (Twigg 2000 s. 79).

Omsorgstagarna å sin sida kan uppleva att närvaron av "främlingar" ställer krav på deras hem och vardag såsom att acceptera föreslagna insatser, arrangera hemmet så att det blir en fungerande arbetsmiljö för personalen, vara flexibel inför att personalens tidsschema kan vara pressat, att inte veta vem av personalen som kommer osv. (Evertsson \& Johansson 2007).

Forskning har visat att äldre och yngre delvis tillmäter hem olika betydelse. För äldre utgör hemmet en manifestation av den egna identiteten och av att man fortfarande är oberoende (Sixsmith \& Sixsmith 1991). Hemmets privata karaktär bidrar till att upprätthålla en känsla av oberoende och personlig identitet (Allan 1989, Kontos 2000, Rowles 1983, 1993, Rowles \& Chaudhury 2005, Rubenstein 1989, Sixsmith 1990).

In terms of identity, the ability to control intrusions into "home territory" is a salient issue. Home plays an important part in framing the experience of independence, since independence is so intimately linked to control (Kontos 2000 s. 268).

Sixsmith (1990) fann att äldre var mer hem- 
orienterade, oftare uppfattade sitt hem som en källa till oberoende samt hade en tydligare emotionell koppling till hemmet än yngre. Av de tillfrågade i Sixsmiths studie ansåg 80 procent att hemmet blivit mera betydelsefullt på äldre dar vilket förklaras med att en allt större del av äldres vardag utspelar sig i det egna hemmet. Äldres betoning av hemmet som arena och källa till oberoende och positiv identitetskänsla är intressant och värd att lägga på minnet då den privata sfär som hemmet representerar snarare tenderar att förknippas med beroende än oberoende i vår del av världen (Fraser \& Gordon 1994). I den mån hem givits betydelse för individers oberoende har det varit i egenskap av möjliggörande resurs för samhällsdeltagande snarare än som en källa och arena för oberoende i sig (Allan 1989). Utan att gå händelserna alltför mycket i förväg vill vi hävda att samma sak gäller för svensk äldrepolitik. Den välfärdspolitiska betoningen på hem och hemmaboende har i mångt och mycket präglats av föreställningen om hemmet som resurs medan hemmet som meningsbärande kontext för äldres vardag, som källa till oberoende och identitet, inte på samma tydliga sätt utgjort grund för hemmaboendeideologins utformning.

\section{Äldres berättelser om hem}

\section{När vardagen förändras}

Mot bakgrund av den vikt som läggs vid att vi som vuxna individer ska vara oberoende är det inte förvånande att många av de intervjuade berättade att de in i det längsta värjde sig mot att ansöka om hemtjänst. De flesta försökte göra som Göta och "leva ungefär som jag levt förut fastän det blir i mindre skalau. De flesta var vana att klara sig själva och måna om att det så skulle förbli.

Jag har alltid klarat mig själv, därför ber jag om så lite hjälp som möjligt. Min man reste jorden runt och var nästan aldrig hemma. Jag skötte huset och tomten samtidigt som jag hade tvåbarn och jobbade. (Linnea)

Ofta var det först i samband med att anhöriga började trycka på eller i anslutning till en sjukhusvistelse som man ansökte om hjälp.

När jag kom ut från lasarettet var det med värk och elände, och sedan dess har jag haft hjälp. Det är ju jättebra att det finns, men frän början skulle jag absolut inte ha det (hjälp från hemtjänsten). Nu är jag bättre och känner att jag kunde börja göra mera själv men barnen är rädd att jag ska bli sämre. (Elsie)

Strävan efter att klara sig på egen hand, rädslan för att bli beroende, fick emellertid hos de flesta ge vika i takt med insikten om att det liv och den vardag man kände och levt började glida dem ur händerna. I likhet med det stora flertalet äldre i Sverige med hemtjänst levde de flesta av intervjupersonerna ensamma (se Socialstyrelsen 2006). Många hade dessutom påtagligt tunna sociala nätverk. Bland de intervjuade uppgav många att vänner och bekanta var döda eller att man tappat kontakten eller av andra skäl var oförmögna att träffas.

Lars Evertsson \& Stina Johansson: Ett hem till mer än namnet... 
Andra uttryck för upplevelsen att vardagen var på väg att glida dem ur händerna var känslan av förlust. Många beskrev ingående hur de sett sig tvingade att sälja villan och/ eller sommarstugan, fått sluta köra bil eller cykla, fått det allt svårare att ta sig ned på stan för att handla, ge upp tidigare hobbies eller att man inte längre betraktades som »någon att räkna med». De allra flesta hade även problem med sviktande eller svag hälsa. Problemet med svag hälsa handlade i mindre utsträckning om hälsan i sig än om dess konsekvenser för det liv man varit van att leva.

Det vore skönt om man kunde gå tillbaka 20 år. Gud vad jag cykla. Jag cyklade tills jag var 80 år. Det var en dam till och jag som cykla. Vi var överallt. Vi tog en kaffeflaska och så for vi. Gud vad jag saknar det. Sen kom operationen av benet och nu tar jag mig inte upp på cykeln längre. De (benen) är som klumpar. (Märta)

I relationen till sjukvården och hemtjänsten upplevdes dock den orkeslösa kroppen som ett misslyckat rehabiliteringsprojekt. Exempelvis var det flera som uttryckte missnöje över att promenaderna med hemtjänsten mer tycktes handla om motion och "gå-träning« än om att skapa möjligheter för dem att komma ut och njuta av vädret eller uträtta ärenden. En kvinna uttryckte tacksamhet över att hon under sommarhalvåret klarade sig utan den gånghjälp hon hade under vinterhalvåret eftersom promenaderna med hemtjänsten var mer stress-än rofyllda. Hon sade sig njuta av sommaren då:

Jag kan gå ut och titta runtikring och se någonting utan att behöva tänka på den där timmen jag hade. Jag kan strosa somjag själv vill. (Inga)

Ett gemensamt drag i dessa berättelser är att känslan av misslyckande och förlust försvårar möjligheten att bibehålla en sammanhängande och positiv identitetskänsla och känsla av att vara oberoende. Den livsstil som tidigare ramade in identiteten har gått förlorad. Det finns, för att använda Giddens (1991) ord, en känsla av sorg och saknad inför kroppens svårigheter att delta i vardagslivets interaktioner och konstituerande normer. En kvinna uttryckte det som att åldrandet var påfrestande för självbilden och att hon fick »jobba hårt för att känna igen sigu.

Du måste finna dig i att ålderdomen har sin begränsning. Det är ålderdomens fel, det är inte ditt fel. Du har inte ändrat personlighet för det. Nu har jag ju kommit i en era med, jag känner inte igen mig själv riktigt somjag var när jag var ung. Jag var produktiv och jag älskade och arbeta och orkade mycket och hann mycket och det gick undan, men nu näe. Slocknad vulkan! (Britt)

\section{En vardag med hemmet $i$ fokus}

Massey (2001) menar att hög ålder och skröplighet ofta innebär en påtaglig inskränkning av det fysiska rummet:

The body imposes some limits. Infirmity and frailty can close down the spaces of older people's lives (Massey 2001 s. 460). 
Denna inskränkning kom tydligt till uttryck i våra intervjuer. I takt med att möjligheten till att förlägga livet utanför hemmet minskade blev det egna hemmet allt viktigare för våra intervjupersoner. Hemmet var en viktig källa till positiv identitetskänsla och utgjorde i sig en manifestation av att fortfarande vara oberoende. Intervjupersonerna talade om hemmet som "själen", "det man byggt upp", "allt man har kvar" och som den plats där man "kan stänga dörren om sigu och får "rå sig själv«. Ett sätt att förstå detta, vilket vi strax ska visa, är att hemmet skapade en plattform för intervjupersonernas identitetsanspråk samtidigt som det gav identiteten en påtaglig social, symbolisk och materiell inramning. På detta sätt blev hemmet en central plats i försöken att balansera och kompensera för upplevelsen av förlust och misslyckanden. Intervjupersonerna kompenserade sitt mer eller mindre ofrivilliga utträde från det offentliga livet med att bygga upp en livsstil knuten till hemmet.

\section{Hemmetsföremål som identitetsbärare}

I intervjuerna kunde vi tydligt se att känslan av hem var intimt kopplat till identitet och strävan efter oberoende. Detta kom tydligt till uttryck i intervjupersonernas relation till föremål i hemmet. Föremål i hemmet - bruksföremål likväl som släktklenoder - användes för att markera identitet och bevara en känsla av samhörighet, sammanhang och kontinuitet (jmf Rubenstein 1992, Saunders 1989). Douglas [1979] (1996 s. 38) menar att "all material posse- sions carry social meanings« och bidrar till att skapa och bibehålla sociala relationer. I en intervju framträder exempelvis ett ganska oansenligt köksbord som bärare av svunna (bättre) tider och relationer. Bordet är egentligen för stort för lägenheten men på grund av det bordet symboliserar har hon inte förmått att göra sig av med det.

Jag har så många minnen. Vi hade ju alltid främmande. Mina syskon - hans (sonen) fastrar och mostrar. De lekte ju och hade så roligt. Då var dom ganska mycket till oss. Och så var det ju maten och bordet. Ja, så många minnen. Man ska ju lämna allt till sist. (Katarina)

I en annan intervju användes släktklenoder för markera ursprung och nära släktband:

De (två glaskupor) är ifrån Backfalls glasblåseri. Glashyttan härute som numera är lantbruksskola. Det är nån gång på 1800talet. Och du ser, dom går lite i grönt. De fick jag av min farmor och farfar när jag var sju år. Väldigt populära. Så det är unikt. Och det här är mammas och pappas lysningspresent (mässingsljusstakar) nerifrån Gärde $i$ Hälsingland där de gifte sig. Gungstolen där, den är amerikansk. Sen 1917. (Inga)

Föremål i hemmet användes även som ett sätt att värja sig mot förändringar och förluster kopplade till identiteten. Föremål i hemmet användes för att, som Douglas [1979](1996 s. 43) uttrycker det, "pin down meaning" och "contain the drift of meaning".

(ip) Instrumenten (gitarr och piano) vill 
jag ha kvar. Dom är viktiga att ha kvar. Jag spelarjupådem.

(i) Fortfarande?

(ip) Nä inte nu inte, men man kan säga att till för ett par år sedan - ja det var svårt då också-innan den (handen) blev förlamad. Dom fär gå i arv sedan. (Carl)

Hemmets roll som skydd mot förändringar framkom även i de erfarenheter som man gjort av att på äldre dar blivit nödd att flytta, oftast på grund av bristande hälsa.

Jag var nästan räddhågad för och släppa villan. Det var ganska besvärligt för mig, övergången att gåoch tittapå en lägenhet och byta ut och sälja bort villan och. $\mathrm{O} j$, jobbigt. Tankarna blir ju, nu ska man börja med ett nytt liv på det här sättet och så. Komma i en lägenhet. Jag brukar säga det att det är en massa knutar. Jag gillar när allting var runt och mjukt. Såjämställde jag det hela. (Carl)

\section{Hemmet som arena för sociala relationer}

Det egna hemmet sågs också som en plats för sociala relationer. Hemmet är en plats för socialt umgänge, här firar man födelsedagar och julaftnar, tar emot vänner och bekanta för en pratstund och en kopp kaffe eller möter grannarna över staket eller i trapphuset. Utan dessa sociala relationer blir identiteten obekräftad och hemmet en tystare och livlösare plats. Ingenstans framträder detta tydligare än hos Britt som av hälsoskäl fått byta bostad och grannar.

Vi hade så trevligt vi grannar. Vi var som en liten familj. Det var ju så härligt, här pratar dom ju aldrig. Säger bara hej. Det här är världens torraste ställe. Jag har aldrig upplevt och varit på nåt ställe som det här. Jag har bott i lägenheter $i$ hela mitt liv och det har varit liv och lust. Här går det ju aldrig att få igång ett samtal med en granne. Och jag har försökt att bjuda hem dom. Jag har burit till dem någon godbit, men det hjälper inte. De kommer aldrig och dricker kaffe med mig eller någonting. Och sånt där saknar jag ju, sånt där behöv man ju. En människa behöver att någon överhuvudtaget vill komma och vara hos en. (Britt)

\section{Hemmet som säte för meningsfull aktivitet}

En tredje aspekt av hem som tydligt kom till uttryck i intervjuerna var betoningen på hemmet som en plats för meningsfull aktivitet. Hemmet representerade en plats där man efter egen förmåga och gottfinnande kunde ägna sig att äta, sova, se på TV, lösa korsord osv. (jmf Nilsson et al. 2006). Hemmet var i detta avseende en manifestation av att man fortfarande var oberoende. Erik menade att:

Sedan jag hamnade i rullstol och inte kan gå till något annat ställe blir hemmet extra viktig. Här fär jag rå mig själv och kan både äta, sova och se TV. (Erik)

Hemmet utgjorde även meningsfull sysselsättning i sig. Att tvätta, städa, laga mat, pynta, byta gardiner med årstidsväxlingar var viktiga för känslan av att överhuvudtaget ha ett hem. I detta avseende utgör hem 
något mer än enbart ett materiellt ankare för vår identitet. Hemmet utgör även »an extension of and mirror for the living body in its everyday activity"(Young 1997 s. 150). På detta sätt bidrar återkommande och välbekanta aktiviteter, eller minimal agency, till att göra vår tillvaro både meningsfull och förutsägbar genom att fixera vår vardag i tid och rum (Honkasalo 2006). Dessa vardagstriviala sysslor bidrar till att upprätthålla vardagens förgivettagna karaktär och skapar en känsla av agens och kontinuitet av identiteten (Schütz 1967). Genom att bemästra vår vardag demonstrerar vi vår sociala kompetens och vårt oberoende som individer inför oss själva och andra. Vår förmåga att upprätthålla en socialt och kulturellt definierad vardag är därför grundläggande för att vi ska framstå som "normala» i mötet med andra (Asplund 1987). Det var därför med en känsla av sorg som många av de vi intervjuade, i brist på ork eller stöd från omgivningen, inte minst från hemtjänstens sida, såg sitt hem förfalla. Många uppgav att hemtrevnaden gått förlorad och en kvinna sade sig direkt vantrivas i sitt hem.

Oj vad hemskt det är. Man orkar inte städa själv. Inte byta gardiner eller så. Och bara hänga upp en tvätt går ju inte. Och ja, jag otrivs när jag har det så hemma. Jag orkar ju inte. Oj vad man saknar det där att kunna städa och vara ut på gården och sköta om blommor och, men det går ju inte. (Flora)

Upplevelsen av »hemmets förfall» fanns hos såväl män som kvinnor. Det fanns dock en viktig skillnad. För kvinnorna var känslan av hem inte bara kopplad till att ha ett fint hem utan också till möjligheten att vara aktiv i det vi ovan beskrivit som vardagstriviala sysslor. De intervjuade kvinnorna hade också betydligt oftare en tydlig uppfattning om på vilket sätt dessa vardagstriviala hushållssysslor skulle utföras. Exempelvis så var det en kvinna som underströk hur viktigt det var att golvet torkades med såpa och ingenting annat:

Såpa vill jag ha och ingenting annat. Det ska lukta rent. (Inga)

För männen var det viktigt att ha ett trivsamt hem, men hushållsarbete i sig hade inget värde för dem (jmf Saunders 1990). Det fick gärna någon annan sköta. Göte berättade att han försökte hålla sig undan när hemtjänsten kom:

När de kommer in i köket går jag och sätter mig framför TV. (Göte)

Erik, talade på skämt om att hyra in en hushållerska för att ta hand om hemmet nu när han själv inte längre orkade.

Man skulle ju ha en sån här husföreståndarinna som det hette förr $i$ värden. Äldre herrar som var änkemän hade ofta husföreståndarinna. Lagar maten och dukar och tvättar och städar och betalar räkningar och går på apoteket och handlar. Men den tiden är över. (Erik)

En möjlig förklaring bakom denna skillnad är att för den generation kvinnor som vi valde att intervjua är uppfattningen av kvinnlighet intimt sammanbundet med förmågan att ta hand om hemmet och dess sysslor medan männen ur samma generation mer tende- 
rar att se hemmet som "... a haven from the pressure of the outside world, even a site for leisure and recreation" (Mallet 2004 s. 75). Douglas (1984) menar att västvärldens kvinnor är kulturellt socialiserade att ta hand om man, barn och hem. Kvinnors husliga arbete är konstituerande för hur vi uppfattar kvinnlighet och för hur vi socialt och kulturellt förstår hem (Gregson \& Lowe 1995, Mason 1989, Massey 1992). I vårt material tog sig detta uttryck i att merparten av kvinnorna fortsatte att kämpa på med att sköta om sitt hem trots att det många gånger tog emot fysiskt. Men som en kvinna sa:

Men jag fär ju sätta mig när jag känner att det är alltför jobbigt. Då sätter jag mig bara en stund. Och så tar jag tag på nytt, stånkar och tar en tablett. Jag tycker att det är terapi, terapi för mig. Det är $i$ den mån jag hinner och orkar och kan. (Inga)

Men ju mer orken tryter desto mer blir hemmets skötsel beroende av, som en kvinna sa, "pigg-dagaru, dvs. dagar då orken faller på.

Förstår ni jag har gjort så här, att ibland när jag haft mina pigg-dagar. För jag har ju nån pigg-dag nån gång, då har jag dammsugit lite grann och så har jag själv satt ut mattan. (Britt)

Det tycks som om en viktig aspekt av känslan av att ha ett hem handlar om hemmets trevnad. Hemmets trevnad är viktig för både män och kvinnor, men med den skillnaden att för kvinnor upplevs sysslor knutna till omsorgen om hemmet som viktiga och meningsfulla aktiviteter. Denna skillnad mellan män och kvinnor är intressant då den pekar på att "hemmets förfall" kan upplevas som en dubbel förlust för kvinnor. Som flera av våra kvinnliga intervjupersoner gav uttryck för så är det mer än hemmets trevnad som står på spel när hemmet började förfalla. I vågskålen ligger också de vardagstriviala göromålen i hemmet som ger struktur och mening åt vardagen och den egna identiteten. Mot denna bakgrund är det rimligt att anta hemtjänstens inställning till äldres hem och »hemmets förfall» får olika långtgående konsekvenser för kvinnor och för män.

Sammanfattningsvis: Intervjuerna visar att hem upplevs som något meningsfullt $i$ sig då det utgör en källa till oberoende och identitet. Denna meningsfullhet ökar ju mer vardagen förläggs till hemmet. Hemmet är ett sätt att balansera/hantera känslan av förlust och misslyckande som följer av att man inte länge förmår förlägga aktiviteter till utanför hemmet. Det är uppenbart från våra intervjuer att hemmet upplevs som någonting mer än enbart en resurs för att bli oberoende. Ett bestående intryck från intervjuerna är att, så länge man upplever sig ha ett hem kommer man att uppfatta sig själv och göra anspråk på att vara oberoende; att ha ett hem är oberoende.

\section{Policyimplikationer för hemtjänsten}

Hemmets centrala betydelse för identiteten och känslan av oberoende kan kasta ljus över den ambivalenta hållning till hemtjänsten som vi fann hos flera av våra intervjupersoner (se även Evertsson \& Johansson 
2007). Å ena sidan var man tacksam att hemtjänsten skapade fysiska förutsättningar att stanna i eget boende. $\AA$ andra sidan var man missnöjd att hemtjänsten inte tog hänsyn till de behov man upplevde sig ha i förhållande till hemmet. Likt Flora i citatet nedan uttryckte flera intervjupersoner besvikelse över att personalen inte såg behovet av hjälp och stöd med hemmet:

Nog tycker jag ändå när dom är här, när dom ser att det skulle behöva sopas eller någonting. Det är ju fort gjort när man är ung och rask. Näe, dom ska inte göra sånt. (Flora)

Men störst var besvikelsen över upplevelsen att hemtjänsten inte ens tycktes villig att erkänna eller överväga behovet av hjälp och stöd med hemmet. Kring dessa arbetsuppgifter fanns sällan något större förhandlingsutrymme. Många delade Britts erfarenhet:

Ja det känns så hemskt att man inte ska kunna få lite utanför paragraferna. Man är som inne i ett fack. Ja, och nu fick jag veta att nu skulle dom ha ett sammanträde och det skulle bli ändå mer skärpt. Nu skulle det va hårda bud. Absolut aldrig gå över gränsen. Det fär du räkna med sa dom. Han satt mig på pottan ordentligt. Då vart jag verkligen förkrossad ännu mer. (Britt)

Det faktum att hem är viktigt för äldres identitet och känsla av oberoende har betydelse för hur vi ser på hemtjänstens inriktning och utformning. Som tidigare sagts så är en bärande tanke i svensk äldreomsorg att äldre vill och mår bäst av att stanna i eget boende så länge som möjligt. Bakom denna välfärdspolitiska tanke finns föreställningen att eget boende gynnar äldres oberoende i betydelsen att de själva kan bestämma/kontrollera sina liv och sin vardag. Men det som på en välfärdspolitisk nivå framstår som en tämligen oproblematisk utgångspunkt blir på en mera konkret nivå, i den kommunala hemtjänsten, högst problematiskt (Johansson 2007). Problematiken består $\mathrm{i}$ att man varken på den välfärdspolitiska nivån eller i hemtjänsten har en klar bild av hur hem och oberoende hänger samman. I en äldrepolitik färgad av den possessiva individualismen finns en tendens att tolka oberoende i termer av fysiskt oberoende, dvs. som frihet från fysiska begränsningar. En betydande del av hemtjänstens insatser har därför kommit att inriktas på att skapa fysiska förutsättningar för äldre att bli kvar i eget boende. Målet för insatserna är att träna omsorgstagarna att klara så mycket som möjligt av vardagens ADL. ${ }^{3}$ Det är förmågan till fysiskt oberoende hos äldre som ska tränas (rehabiliteras och habiliteras) och vidmakthållas. Mycket av hemtjänstens insatser kretsar kring att bibehålla rutiner såsom att stiga upp på morgonen, klä sig rent och ändamålsenligt (inte gå klädd i pyjamas eller morgonrock under dagen), sköta sin hygien och klara toalettbestyr, äta och klara medicinering. Kort sagt att skapa förutsättningar för att den enskilde omsorgstagaren fysiskt ska kunna stanna i eget boende. ${ }^{4}$

3 Activity of Daily Living

4 Socialstyrelsen (2004) pekar på ett ökat framtida behov av vård och rehabilitering/ habilitering inom äldreomsorgen. 
Inom svensk äldrepolitik finns en tydlig slagsida mot att se hemmet endast som en resurs och plattform för ett liv utanför hemmet. Men med tanke på vår kulturella föreställning av oberoende som någonting individen tillägnar sig och vidmakthåller genom deltagande i den offentliga sfären är detta kanske inte så mycket att förvånas över. Mot denna bakgrund förefaller det fullt rimligt att lägga kraften på att (re)habilitera äldres fysiska förmåga. Resursperspektivet på hem innebär emellertid en olycklig insnävning då frågor som rör hemmet som källa och arena för äldres oberoende och identitet förblir ouppmärksammade och oproblematiserade. Detta är en svaghet i svensk äldrepolitik.

De fysiska förutsättningarna för äldres möjlighet att stanna i eget boende är självfallet viktiga att understödja. Samtidigt är det viktigt att inte glömma bort de sociala förutsättningarna för omsorgstagarnas möjlighet att stanna i ett eget boende. I den här artikeln har vi pekat på betydelsen av hem som en viktig social förutsättning för kvarboende. Som vi försökt visa utgör hemmet en viktig källa till oberoende och positiv identitetskänsla. Genom att koppla behovet av stöd i vardagen till äldres kroppar riskerar hemtjänstens insatser att frikopplas från den sociala betydelsen av hem.
Sixsmith (1990), som studerat den engelska motsvarigheten till vår hemtjänst, menar att tendensen att betrakta åldrandet som ett problem kopplat till "bodies in need" inneburit att boende kommit att betraktas som en praktisk fråga, dvs. hur äldres boende praktiskt ska ordnas, snarare än hur hemmet i sig utgör en meningsfull kontext i äldres vardag.

Sammanfattningsvis: Mot bakgrund av den centrala position som hem givits $i$ svensk äldrepolitik är det viktigt att rikta uppmärksamhet mot såväl de fysiska som sociala förutsättningarna för äldres möjligheter att stanna i eget boende. Intervjuerna visar dock att många omsorgstagare upplever brister vad gäller de sociala förutsättningarna att stanna i eget boende, särskilt möjligheten att vidmakthålla känslan av att faktiskt bo kvar i sitt eget hem. Sett utifrån hemmaboendeideologins välfärdspolitiska intentioner är detta olyckligt eftersom känslan av hem hos äldre är nära kopplat till upplevelsen av att vara oberoende och till identiteten. Äldrepolitikens tanke om äldres hem som en central resurs i ett gott åldrande kräver därför ett beaktande av såväl de fysiska som sociala förutsättningarna för äldres kvarboende. Om så inte sker riskerar hemmet som resurs för äldres oberoende och identitet förbli oinfriat löfte. 


\section{Referenser}

Allan, Graham (1989) "Insiders and Outsiders: Boundaries around the home." I Graham Allan \& Graham Crow (eds.) Home and Family: Creating the Domestic Sphere. Basingstoke: Macmillan.

Asplund, Johan (1987) Det sociala livets elementära former. Göteborg: Bokförlaget Korpen.

Attwood, Feona (2005) "Inside Out: Men on the 'Home Front'." Journal of Consumer Culture vol. 5 no 1, pp. 87-107.

Barron, Karin (1996) „Ung och funktionshindrad i ett föränderligt samhälle.» I Magnus Tideman (red.) Perspektiv på funktionshinder och handikapp. Stockholm: Johansson \& Skyttmo förlag.

Berner, Boel (1989) Kunskapens vägar. Teknik och lärande i skola och arbetsliv. Lund: Arkiv förlag.

Borell, Klas \& Johansson, Roine (2005) „Det egna hemmet som andras arbetsplats." I Björn Fjæstad \& Lars-Erik Wolvén (red.) Arbetsliv och samhällsförändringar. Lund: Studentlitteratur.

Butler, Judith (1999) Gender Trouble: Feminism and the Subversion of Identity. New York: Routledge.

Després, Carole (1991) »The Meaning of Home: Literature Review and Directions for Future Research and Theoretical Development." Journal of Architectural and Planning Research vol. 8 no 2, pp. 97-115.

Douglas, Mary (1984) Purity and Danger. An Analysis of the Concepts of Pollution and Taboo. London: Ark Paperbacks.

Douglas, Mary \& Isherwood, Baron [1979](1996) The World of Goods: towards an anthropology of consumption. London: Routledge.

Edebalk, Per-Gunnar (1990) Hemmaboendeideologins genombrott: åldringsvård och socialpolitik 1945-1965. Meddelanden från socialhögskolan i Lund 1990:4. Lund: Socialhögskolan.

Evertsson, Lars \& Johansson, Stina (2007) "Springet i hemtjänsten." I Stina Johansson (red.) Social omsorg $i$ socialt arbete. Malmö: Gleerups Utbildning AB.

Fraser, Nancy \& Gordon, Linda (1994) „A Genealogy of Dependency: Tracing a Keyword of the
U.S. Welfare State.« Signs vol. 19 no 2, pp. 309336.

Giddens, Anthony (1991) Modernity and SelfIdentity: Self and Society in the Late Modern Age. Cambridge: Polity Press.

Goffman, Erving (1971) Relations in Public: Microstudies of the Public Order. New York: Basic Books.

Goffman, Erving (1972) Stigma: Den avvikandes roll och identitet. Stockholm: Prisma.

Gorman-Murray, Andrew (2006) "Queering Home or Domesticating Deviance?: Interrogating Gay Domesticity Through Lifestyle Television." International Journal of Cultural Studies vol. 9 no 2, pp. 227-247.

Gregson, Nicky \& Lowe, Michelle (1995). "'Home'making: on the spatiality of daily social reproduction in middle class Britain." Transactions Institute of British Geographers vol. 20 no 2, pp. 224-335.

Hall, Stuart (1996) "Introduction: who needs identity?" I Stuart Hall \& Paul du Gay (eds.) Questions of Cultural Identity. London: Sage.

Hockey, Jenny \& James, Allison (1993) Growing Up and Growing Old: Ageing and Dependency in the Life Course. London: Sage Publications.

Honkasalo, Marja-Liisa (2006) "Fragilities in life and death: Engaging in uncertainty in modern society." Healt, Risk \& Society vol. 8 no 1, pp. 27-41.

Johansson, Mairon (2007) Gamla och nya frivillighetsformer - ädreomsorgshybrider växer fram. Rapportserie Socialt arbete nr. 2, 2007 (Lic. avhandling). Växjö: Växjö universitet.

Kontos, Pia C (2000) »Resisiting Institutionalization: Constructing Old Age and Negotiating Home.« I Jaber F Gubrium \& James A Holstein (2000) Aging and Everyday Life. Oxford: Blackwell Publishers.

Laslett, Peter [1989](1996) A fresh map of life: emergence of a Third Age. London: Macmillan Press.

MacFarlane, Alan (1978) The origins of English individualism: the family, property and social

Lars Evertsson \& Stina Johansson: Ett hem till mer än namnet... 
transition. Oxford: Basil Blackwell

Macpherson, C.B [1962] (1967) The Political Theory of Possessive Individualism: Hobbes to Locke. Oxford: Oxford University Press Paperbacks.

Mallet, Shelley (2004) „Understanding home: a critical review of the litterature." The Sociological Review vol. 52 no 1, pp. 62-89.

Mason, Jennifer (1989) »Reconstructing the Public and the Private: The Home and Marriage in Later Life." I Graham Allan \& Graham Crow (eds.) Home and family: creating the domestic sphere. Basingstoke: Macmillan.

Massey, Doreen B (1992) "A Place called Home?" New Formations no 17, pp. 3-15.

Massey, Doreen B (2001) "Living in Wythenshewe." I Ian Borden, Joe Kerr, Jane Rendell \& Alicia Pivaro (eds.) The Unknown City: Contesting Architecture and Social Space. Cambridge, MA: The MIT Press.

Merriam, Sharan B (1994) Fallstudien som forskningsmetod. Lund: Studentlitteratur.

Nilsson Ingeborg, Löfgren Britta, Fisher Anne G \& Bernspång Birgitta (2006) "Focus on Leisure Repertoire in the Oldest Old: The Umeå 85+ Study.u Journal of Applied Gerontology vol. 25 no 5, pp. 391-405.

Patton, Michael Quinn (1980) Qualitative Evaluation Methods. Beverly Hills, California: Sage.

Regeringens proposition 1997/98:113. Nationell handlingsplan för äldrepolitiken. Stockholm.

Rowles, Graham D. (1983) „Place and Personal Identity in Old Age: Observations from Appalachia." Journal of Environmental Psychologyvol. 3, pp. 299-313.

Rowles, Graham D. (1993) „Evolving Images of Place in Aging and'Aging in Place'." Generations vol. 17 no 2, pp. 65-70.

Rowles, Graham D. \& Chaudhury, Habib (eds.) (2005) Home and Identity in Late Life: international perspectives. New York: Springer.

Rubenstein, Robert L (1989) »The Home Environments of Older People: A Description of the Psychosocial Processes Linking Person to Place." Journal of Gerontology, Social Sciences vol. 44 no 2, pp. 45-53.
Rubenstein, Robert L (1992) »The significance of Personal Object to Older People." I Jaber F Gubrium \& Kathy Charmaz (eds.) Aging, Self, and Community: A Collection of Readings. London: JAI Press Inc.

Saunders, Peter (1989) »The Meaning of 'Home' in Contemporary English Culture."Housing Studies vol. 4 no 3, pp. 177-192.

Saunders, Peter (1990) A Nation of Homeowners. London: Unwin Hyman.

Schütz, Alfred (1967) Collected Papers I: The problem of social reality. The Hague: Maurice Natanson Phaenomenologica.

Sibley, David (1995) Geographies of Exclusion: Society and Difference in the West. London: Routledge.

Sidenvall Birgitta, Nydahl Margaretha \& Fjellström, Christina (2001) „Managing food shopping and cooking: the experiences of older women." Ageing and Society vol. 21, pp. 151168.

Sixsmith, Andrew J(1990) „The meaning and experience of 'home' in later life.» I Bill Bytheway \& Julia Johnson Welfare and the Ageing Experience: a multidisciplinary analysis. Aldershot: Avebury cop.

Sixsmith, Andrew J \& Sixsmith, Judith A (1991) "Transitions in Home Experience in Later Life." Journal of Architectural and Planning Research vol. 8 no 3, pp. 181-191.

Socialstyrelsen (2004) Investera nu! Handlingsplan för kompetensförsörjning inom vård och omsorg. Publicerad: www.socialstyrelsen.se

Socialstyrelsen (2006) Omsorg människor emel lan. Publicerad: www.socialstyrelsen.se

Sommerville, Peter (1997) "The Social Construction of Home." Journal of Architectural and Planning Research vol. 14 no 3, pp. 227-245.

Starrin Bengt, Larsson Gerry, Dahlgren Lars \& Styrborn Sven (1991) Från upptäckt till presentation. Om kvalitativ metod och teorigenerering på empirisk grund. Lund: Studentlitteratur.

Sundström, Gerdt \& Johansson, Lennarth (2004) Sharing in Caring. Paper presented at $17^{\text {th }}$ Nordic Congress in Gerontology, 23-26 May in Stockholm. 
Taylor, Charles (1989) Sources of the Self: the making of the modern identity. Cambridge: Cambridge University Press.

Twigg, Julia (2000) Bathing: The Body and Community Care. London: Routhledge.

Varley, Ann (2008) „A place like this? Stories of dementia, home, and the self." Environment and Planning D: Society and Space vol. 26, pp. 47-67.
Wardaugh, Julia (1999) »The Unaccommodated Woman: Home, Homelessness and Identity." The Sociological Review vol. 47 no 1 , pp. 91-109.

Young, Iris Marion (1997) Intersecting Voices: Dilemmans of Gender, Political Philosophy, and Policy. Princeton, NJ: Princeton Paperbacks.

\section{Summary}

\section{A home to live in \\ Home as a source of independence and identity among elderly with home-based community care}

An important aim for Swedish elderly care is to make it possible for frail elderly people to remain living in their own homes since home, it is argued, is a vital resource for independent ageing. Our interviews with elderly with home-based community care show, however, that the importance that is attributed to home exceeds the notion of home as a resource. Home has a more profound meaning; it is seen as a source of independence and an expression of identity. In the article we argue that the shift in perspective, from home as a resource to home as source of independence and an expression of identity, carries welfare-political implications. The perspective on home as a source of independence surpasses the prevailing notion of independence as something that a person achieves outside of home. The emphasis put on home by the elderly, as a source of independence and an expression of identity, points to the need and importance of services that address elderly people's difficulties in upholding their sense of home. 